\title{
0271-5198(95)00055-0
}

\section{CONTENTS OF BIORHEOLOGY, VOLUME 32, NUMBER 4}

\begin{tabular}{|c|c|c|}
\hline & & Editorial \\
\hline & & Papers \\
\hline R. Yamamoto & 421 & $\begin{array}{l}\text { Defendence of water conductivity on } \\
\text { pressure and temperature in plant } \\
\text { stems }\end{array}$ \\
\hline $\begin{array}{l}\text { M. Marquart, A. M. Jamieson, } \\
\text { J. Blackwell and T. Gerken }\end{array}$ & 431 & $\begin{array}{l}\text { Solvent effects on the viscoelastic } \\
\text { behavior of porcine submaxillary mucin }\end{array}$ \\
\hline X. He and D. N. Ku & 447 & $\begin{array}{l}\text { Flow in T-bifurcations: Effect of the } \\
\text { sharpness of the flow divider }\end{array}$ \\
\hline $\begin{array}{l}\text { M. I. Cohen, D.-M. Wang and } \\
\text { J. M. Tarbell }\end{array}$ & 459 & $\begin{array}{l}\text { Measurement of oscillatory flow } \\
\text { pressure gradient in an elastic } \\
\text { artery model }\end{array}$ \\
\hline $\begin{array}{l}\text { A. Rachev, S. E. Greenwald, } \\
\text { T. P. C. Kane, J. E. Moore, Jr. } \\
\text { and J.J. Meister }\end{array}$ & 473 & $\begin{array}{l}\text { Analysis of the strain and stress } \\
\text { distribution in the wall of the } \\
\text { developing and mature rat aorta }\end{array}$ \\
\hline \multirow[t]{4}{*}{$\begin{array}{l}\text { S. Chen, B. Gavish, S. Zhang, Y. Mahler } \\
\text { and S. Yedgar }\end{array}$} & 487 & $\begin{array}{l}\text { Monitoring of erythrocyte } \\
\text { aggregate morphology under flow } \\
\text { by computerized image analysis }\end{array}$ \\
\hline & 497 & Erratum \\
\hline & 499 & Announcement \\
\hline & 501 & $\begin{array}{l}\text { Contents of Clinical Hemorheology, } \\
\text { Volume 14, Number } 6\end{array}$ \\
\hline
\end{tabular}

